\title{
'Quonset' Juniper
}

\section{G.E. Evans ${ }^{1}$, R.E. Gough ${ }^{2}$, and H. Metcalf ${ }^{3}$ \\ Department of Plant, Soil, and Environmental Sciences, Montana State University, Bozeman, MT 59717-0312}

\begin{abstract}
Additional index words. Juniperus scopulorum $\times$ J. horizontalis, cascading juniper, cold
\end{abstract} tolerance

Landscape plants that tolerate dry, cold conditions associated with the northern Great Plains are useful and rare. Junipers (Juniperus L.) do well under these conditions, but their growth habits are limited generally to conical, horizontal, or spreading. A new juniper that is well adapted to harsh growing conditions and exhibits a completely different, cascading habit of growth would be a welcome addition to the list of plants available to homeowners and nurseries in this climatic zone.

\section{Origin}

'Quonset' is a pistillate seedling grown from seed collected from a population of Juniperus scopulorum Sarg. in the Fort Peck Reservoir area of northeastern Montana by Homer Metcalf in 1952. Since the mother plant grew in proximity to plants of $J$. horizontalis Moench., and since 'Quonset' displays attributes of both species, we believe it is a hybrid of the two. The suspected parents, both diploids, have an identical compliment of chromosomes $(2 n=22)$ (Darlington and Wylie, 1955; Mehra and Khoshoo, 1956). The name 'Quonset' is taken from a Quonset hut constructed near the plant.

\section{Description}

'Quonset' juniper is vigorous on a good planting site. The original mother plant is now about $1 \mathrm{~m}$ tall at its center and has a diameter of $4 \mathrm{~m}$ (Fig. 1). The plant has a horizontal form resembling that of $J$. horizontalis during its early years and then assumes a mounded habit after the first decade of growth. The overall mature effect is one of branches weeping or cascading from a mounded shrub. Its central portion resembles the mounded habit of Savin juniper (J. sabina var. tamariscifolia Ait.); the surrounding portions are more horizontal, with a habit similar to $J$. horizontalis. This habit is the unique character of the cultivar. Foliage is composed primarily of awl-like juvenile leaves.

\footnotetext{
Received for publication 20 Feb. 1996. Accepted for publication 5 June 1996. Montana Agr. Expt. Sta. contribution no. J-4092. The cost of publishing this paper was defrayed in part by the payment of page charges. Under postal regulations, this paper therefore must be hereby marked advertisement solely to indicate this fact.

${ }^{1}$ Professor Emeritus.

${ }^{2}$ Associate Professor, to whom reprint and propagation material requests should be addressed.

${ }^{3}$ Professor Emeritus, deceased.
}

During the test period on an open site at Bozeman (elevation $1566 \mathrm{~m}$ ), 'Quonset' survived extremes in temperatures ranging from $-40^{\circ} \mathrm{C}$ to $40^{\circ} \mathrm{C}$, open winters with little snow, winters with heavy snow cover, and years with extended midwinter thaws. No injury from environmental factors or pests has ever been noted.

\section{Propagation}

'Quonset' can be propagated by stem cuttings collected in January, wounded at their base, dipped in Hormodin 3 (Merck Chemical Division, Merck and Co., Rahway, N.J.), stuck in a 50 peat : 50 sand mixture $(\mathrm{v} / \mathrm{v})$, and maintained under an intermittent mist for several months.

\section{Availability}

Requests for information and availability of propagation material should be directed to R.E.G., Dept. of Plant, Soil, and Environmental Sciences, Montana State Univ., Bozeman, MT 59717-0312.

\section{Literature Cited}

'Quonset' has displayed no obvious symptoms of cedar-apple rust (Gymnosporangium juniperi-virginianae Schw.). This situation is especially unusual since both of the suspected parents are susceptible to the pathogen (Hepting, 1971). We have observed no disease infection or insect infestations over the 43year test period, including those of twig blight (Phomopsis juniperovora Hahn.), spider mites (Oligonychus ununguis Jacobi or Tetranychus urticae Koch), and scale (Carulaspis juniperi Bouche).

Darlington, C.D. and A.P. Wylie. 1955. Chromosome atlas of cultivated plants. 2nd ed. Geo. Allen and Unwin, London.

Hepting, G.H. 1971. Diseases of forest and shade trees of the United States. U.S. Dept. Agr. Forest Serv. Agr. Hdbk. 386.

Kollmorgen Corporation. 1976. Munsell book of color. Munsell Color, Macbeth Division, Baltimore.

Mehra, R.N. and T.N. Khoshoo. 1956. Cytology of conifers I. J. Genet. 54:165-180.

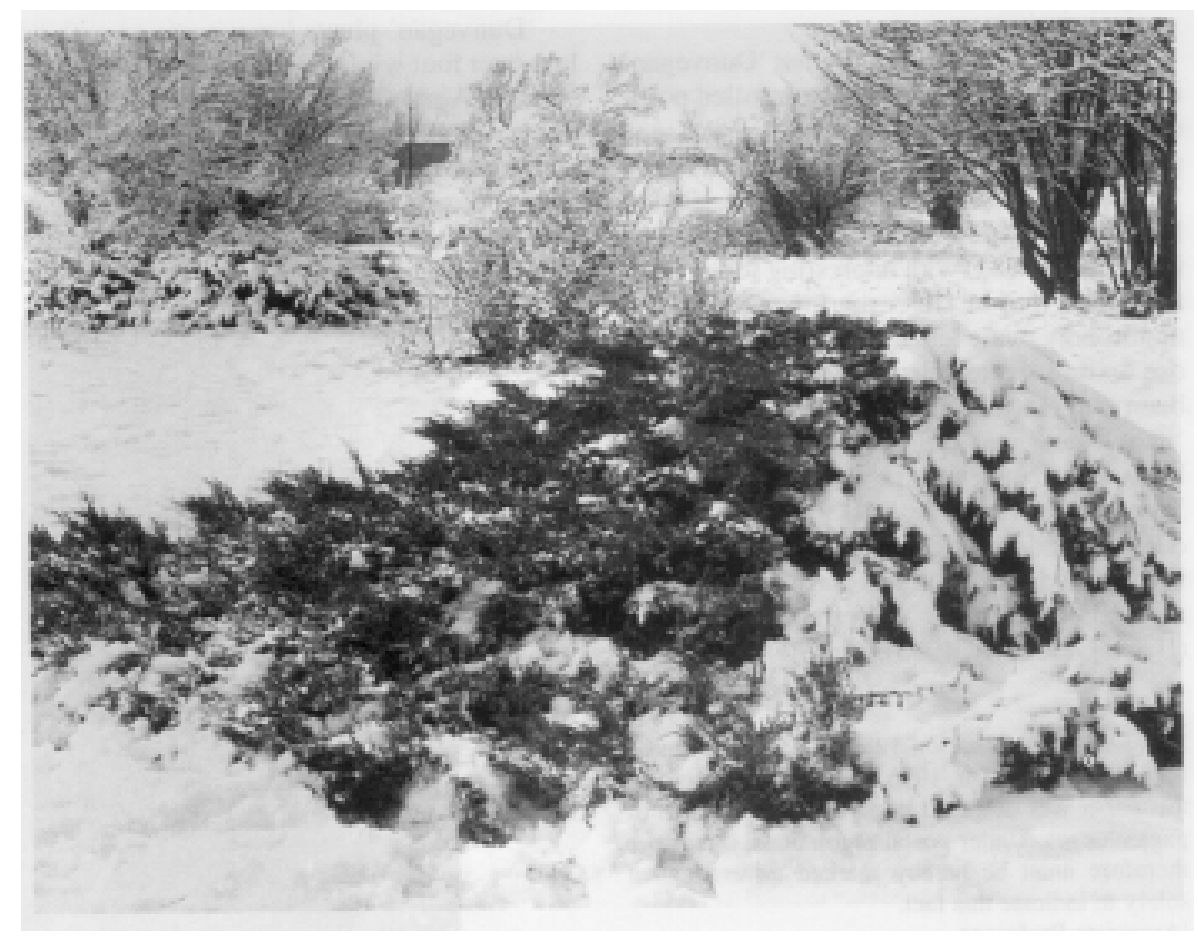

Fig. 1. A 40-year-old specimen of 'Quonset' juniper growing at the Horticulture Research Farm, Montana State Univ., Bozeman. Note the cascading habit. 